\title{
Differential Withdrawal of Retinal Axons Induced by a Secreted Factor
}

\author{
Hiroyuki Ichijo ${ }^{1,2}$ and Friedrich Bonhoeffer ${ }^{2}$ \\ ${ }^{1}$ Department of Anatomy, Institute of Basic Medical Sciences, University of Tsukuba, Tsukuba, Ibaraki 305-8575, Japan, \\ and ${ }^{2 M a x}$-Planck-Institut fuer Entwicklungsbiologie, Abteilung Physikalische Biologie, 72076 Tuebingen, Germany
}

To understand the development of the topographic map in the chick retinotectal projection, we studied the long-term interactions between retinal axons and tectal cell processes using a novel coculture system, the ryomen chamber. Both nasal and temporal retinal axons initially grew equally well on a substrate consisting of posterior tectal cell processes; however, subsequently most temporal axons withdrew from this surface, whereas most nasal axons did not. Experiments using conditioned media indicate that posterior tectal cells induced withdrawal of the temporal axons by secreting a soluble factor. This withdrawal seems to be distinct from the immediate repulsive effect of ephrin-A2 (ELF-1) and ephrin-A5 (RAGS) seen in the stripe assay because (1) the withdrawal-inducing factor was diffusible, whereas ephrin-A2 and -A5 are membrane-bound, and (2) the withdrawal-inducing factor appeared later in development than ephrin-A2 and -A5. Furthermore, sensitivity to the withdrawal-inducing factor decreased continuously from the temporal to nasal retina. These results suggest that target cell-induced axonal withdrawal may be involved during a late stage of the development of the retinotectal map.

Key words: axon guidance; retinotectal projection; topographic map; remodeling; chick embryo; neural development; repulsive factors
A basic question in developmental neurobiology is how axons select specific pathways and connect with specific cells within target regions (Tessier-Lavigne and Goodman, 1996). To explore the mechanisms for axonal guidance, retinotectal projections have long been good models because of their strict topographic projection rules [nasal and temporal retinal ganglion cells (RGCs) project to the posterior and anterior optic tectum, respectively, whereas dorsal and ventral RGCs project to the ventral and dorsal optic tectum, respectively]. Neighboring RGCs tend to establish neighboring terminal fields in the tectum (Crossland et al., 1974; Fujisawa, 1981; Stuermer, 1988; Nakamura and O'Leary, 1989).

Sperry (1963) assumed in his chemoaffinity hypothesis that RGCs and tectal neurons have chemical labels that specify cell positions and function as guidance cues. It is thought that RGC axons should distinguish between cells from different positions by the guidance cues expressed as a set of gradients in the tectum (Easter and Stuermer, 1984; Constantine-Paton et al., 1986; Gierer, 1987; Rabacchi et al., 1990; McLoon, 1991; Cheng et al., 1995; Drescher et al., 1995; Savitt et al., 1995; Honda, 1998).

\footnotetext{
Received Jan. 6, 1998; revised April 17, 1998; accepted April 22, 1998.

This work was supported in part by Grants-in-Aid for Scientific Research 08780719 and 09780701 from the Ministry of Education, Science, and Culture, Japan. H.I. was supported by the TOYOBO Biotechnology Research Foundation in Osaka, Japan, and the Max-Planck-Gesellschaft in Germany. We thank Drs. A. Crawford, R. Karlstrom, B. Monschau, B. Mueller, and S. Rosentreter for their critical readings of this manuscript and for their help with the language, and Dr. Juergen Loeschinger for introducing the collapse assay technique. Anti G4, ephrinA5, and ephrin-A2 monoclonal antibodies were kindly provided by Drs. Y. von Boxberg and H. Tanaka. EphA3-AP, ephrin-A5-AP, and ephrin-A2-AP fusion proteins were donated by Drs. U. Drescher, C. Kremoser, and B. Monschau. We acknowledge gratefully the assistance of J. Berger, B. Diehl, J. Huf, K.-H. Nill, B. Sailer, J. Sakamoto, G. Scheer, and S. Schaefter.

Correspondence should be addressed to Dr. Hiroyuki Ichijo, Department of Anatomy, Institute of Basic Medical Sciences, University of Tsukuba, Tsukuba, Ibaraki 305-8575, Japan.

Copyright (C) 1998 Society for Neuroscience $\quad 0270-6474 / 98 / 185008-11 \$ 05.00 / 0$
}

Short-distance interactions have been revealed in vitro between RGC growth cones and tectal cell bodies (Bonhoeffer and Huf, 1982; Johnston and Gooday, 1991; Davenport et al., 1996, 1998), between RGC growth cones and tectal cell membranes (Walter et al., 1987a,b; Simon and O'Leary, 1992; von Boxberg et al., 1993; Roskies and O'Leary, 1994), and between RGC axons and soluble proteins prepared from the tectum (Carri and Ebendal, 1987). In the stripe assay (Walter et al., 1987a,b), temporal retinal axons avoid posterior tectal membranes and prefer to grow on anterior tectal membranes, although nasal axons grow on both anterior and posterior tectal membranes. The results indicate that one or more factors in the posterior tectal membranes repel temporal axons. The Eph ligands, ephrin-A2 and ephrin-A5, are thought to be responsible at least in part for the repulsive activity of posterior tectal membranes (Cheng et al., 1995; Drescher et al., 1995; Nakamoto et al., 1996; Monschau et al., 1997; Frisén et al., 1998).

Development of the retinotectal map consists of two stages in higher vertebrates (Nakamura and O'Leary, 1989; Simon and O'Leary, 1992; Mark et al., 1993). For example, in the chick, temporal axons are distributed with a strong bias over the anterior tectum, the correct region, by embryonic day 11 (E11). A more precise map is established by E16 because of remodeling: branching of the growth cones, backbranching from the axonal shafts, and subsequent removal of aberrant branches by their retraction and cell death. In the rat, the initial map is very diff use at postnatal day $2(\mathrm{P} 2)$. This map is remodeled and is quite precise by $\mathrm{P} 12$. Because ephrin-A2 and -A5 are expressed during the initial stage of the map development in the chick, they may lead to the formation of an initial crude projection in vivo. However, they may not be sufficient to generate a final precise map. We do not know the mechanisms underlying the remodeling of the map.

To understand the development of the retinotectal map in the chick, especially in terms of the remodeling, we devised a method 
for culturing retinal and tectal cells on the two sides of a filter, which allows both contact- and diffusion-mediated interactions; retinal and tectal processes contact each other through the filter pores although separating their cell bodies, and retinal axons are influenced by the tectal cells through a soluble factor secreted from the penetrated tectal processes (see Fig. 1). We named the method the ryomen chamber assay (ryomen is the Japanese term for "double-sided"). This method allowed long-term and longdistance interactions between retinal axons and tectal processes. Posterior tectal cells induced the withdrawal of temporal retinal axons in vitro by a diff usible factor. The results raise the possibility that the target-induced axonal withdrawal might account for the late stage of the map development, such as remodeling of the crude projection into the precise map.

\section{MATERIALS AND METHODS}

The ryomen chamber. We developed a coculture system to investigate long-term interactions between the RGC axons and the tectal cells processes, mediated through both contact and diffusion. It consists of a pair of stainless steel rings holding a Nuclepore filter (see Fig. 1A). The inner and outer diameters of the rings were 10 and $50 \mathrm{~mm}$, respectively. The Nuclepore filter with pores of $0.6 \mu \mathrm{m}$ in diameter was treated overnight at $37.8^{\circ} \mathrm{C}$ with a diluted Matrigel (Becton Dickinson, Bedford, MA) solution containing $1 \mathrm{mg} / \mathrm{ml}$ of total protein in HBSS. The filter was inserted between the rings and sealed with silicone paste (highly viscous; Boehringer Mannheim, Mannheim, Germany). One side of the filter, the tectal side, was used for culturing tectal cells; the other side, the retinal side, served for the growth of retinal axons.

Culturing tectal cells in the ryomen chamber. Fertilized chicken eggs were obtained from local farms. They were incubated at $37.8^{\circ} \mathrm{C}$ for $7 \mathrm{~d}$. Optic tecta were dissected from E7 embryos in ice-cold HBSS. The anterior third and posterior third of the tecta were used. For mapping nasotemporal transitions in the retina, the tecta were subdivided along the anterior-posterior axis into six parts, which were tested separately. The tissues were cut into pieces in the HBSS and subsequently treated with a trypsin-EDTA solution (Sigma, St. Louis, MO) for $10 \mathrm{~min}$ at $37.8^{\circ} \mathrm{C}$. Trypsinization was stopped by adding fetal bovine serum. Cell suspensions were prepared by trituration and washed twice in an F12 culture medium consisting of F12 nutrient mixture, $10 \%$ fetal bovine serum (Life Technologies, Rockville, MD), 2\% chick serum, 2 mm L-glutamine, and penicillin-streptomycin. Five hundred microliters of cell suspensions $\left(0.7 \times 10^{7}\right.$ cells $\left./ \mathrm{ml}\right)$ were cultured on the tectal side of the filter overnight at $37.8^{\circ} \mathrm{C}$ in $5 \% \mathrm{CO}_{2}$.

The next day, the cultured media were recovered, centrifuged to remove cellular debris, and mixed with the same volume of fresh F12 culture medium. Twenty-five microliters of Matrigel were added to the tectal side. After an incubation for $30 \mathrm{~min}$ at $37.8^{\circ} \mathrm{C}$ in $5 \% \mathrm{CO}_{2}$, the chambers were turned upside down to make the other side, the retinal side, of the filter available.

Culturing retinal explants in the ryomen chamber. Neural retinae from E6 embryos were prepared as described by Halfter et al. (1983). The retina was chopped parallel to the optic fissure with a tissue chopper (Mickle Laboratory Engineering) to make 0.3-mm-wide retinal strips. The strips were divided into a nasal or temporal group and numbered serially from the center to the periphery. Numbers 4,5 , and 6 of the nasal or temporal strips were used in all experiments except for the mapping experiments. In the standard overnight preculture experiments, they were explanted on the retinal side of the filter immediately after the filter had been turned upside down. Nine hundred microliters of medium, a mixture of the cultured and fresh medium, were added to each culture (see Fig. 1B). Half of the volume of the medium was exchanged with the fresh medium on the third and fifth day after retinal explantation.

In the long preculture experiments for $4 \mathrm{~d}$, the tectal substrates were first cultured for $3 \mathrm{~d}$ with no retinal explant after being turned upside down. Subsequently, at day 4, retinal explants were added to the culture and incubated for an additional 3 or $7 \mathrm{~d}$.

Scanning electron microscopy. On the third day of the tectal cultures, the substrates were fixed with $4 \%$ paraformaldehyde (PFA) in PBS overnight at room temperature and with $2.5 \%$ glutaraldehyde in PBS for $1 \mathrm{hr}$. Then, they were post-fixed with $1 \% \mathrm{OsO}_{4}$ in $\mathrm{PBS}$ for $1 \mathrm{hr}$ on ice and stained with $1 \%$ uranyl acetate for $1 \mathrm{hr}$. Finally, they were dehydrated, critical point-dried, and coated with gold and palladium for scanning electron microscopy.

Immunohistochemistry. The cultures were fixed on the third, fifth, or seventh day after retinal explantation with 4\% PFA in PBS overnight at room temperature. Retinal axons were stained as whole mounts with an antibody against G4/NgCAM (Rager et al., 1996). The cultures were also stained with antibodies against microtubule-associated protein-2 (MAP2) (Sigma), vimentin (Boehringer Mannheim), and glial fibrillary acidic protein (GFAP) (Sigma). They were subsequently incubated with the appropriate Cy3-coupled secondary antibodies (Jackson ImmunoResearch, West Grove, PA) and then examined and photographed under a fluorescence microscope (Axiophot, Zeiss).

Receptor affinity probe in situ histochemistry with an EphA3-alkaline phosphatase fusion protein. Receptor affinity probe (RAP) provides a simple histochemical tool to detect the expression of a ligand (Flanagan and Leder, 1990; Cheng and Flanagan, 1994). EphA3 is one of the receptors for ephrin-A2 and ephrin-A5, previously characterized repulsive factors in the chick retinotectal system. Drs. Kremoser, Monschau, and Drescher in Tuebingen produced EphA3-AP by fusing the ligand binding domain of the EphA3 tyrosine kinase receptor to a heat-stable alkaline phosphatase. The tectal substrates were fixed on the third or seventh day in culture with $3.7 \%$ formaldehyde in PBS for $30 \mathrm{~min}$ and rinsed twice in PBS. They were incubated in an EphA3-AP solution (10 $\mathrm{nM})$ for $4.5 \mathrm{hr}$ at room temperature, then washed six times in HBHA buffer (HBSS with $0.5 \mathrm{mg}$ of bovine serum albumin, $0.02 \% \mathrm{NaN}_{3}$, and 20 mM HEPES, pH 7.3). They were refixed with $60 \%$ acetone and $3.7 \%$ formaldehyde for $30 \mathrm{sec}$, rinsed twice in HEPES-buffered saline $(150 \mathrm{~mm}$ $\mathrm{NaCl}$ and $20 \mathrm{~mm}$ HEPES, $\mathrm{pH} 7.3$ ), and incubated at $65^{\circ} \mathrm{C}$ for $15 \mathrm{~min}$ to inactivate intrinsic alkaline phosphatases. They were equilibrated in AP-buffer (100 mM Tris, $\mathrm{pH} 9.5,100 \mathrm{~mm} \mathrm{NaCl}$, and $1 \mathrm{~mm} \mathrm{MgCl}_{2}$ ), and incubated in AP-substrate-buffer (AP-buffer with $0.45 \mathrm{mg} / \mathrm{ml}$ of nitroblue tetrazolium and $0.175 \mathrm{mg} / \mathrm{ml}$ of 5-bromo-4-chloro-3-indolylphosphate $p$-toluidine salt) overnight at room temperature.

Quantitative analysis in the ryomen chamber assay. In the ryomen chamber assay, maximum densities of axonal bundles were measured. An area with the highest axonal density was chosen by microscopic observation and photographed with a $10 \times$ objective lens, and the image was digitized with a film scanner (Nikon, Tokyo, Japan). By using the National Institutes of Health image software (version 1.60, Wayne Rasband), pixels over axonal bundles were counted in a $0.5 \mathrm{~mm}^{2}$ area, and the density of axonal bundles $\left(\mathrm{mm}^{2} / \mathrm{mm}^{2}\right)$ was calculated. The measurement correlated well with other methods, e.g., measurement of the diameter of axonal halos or number of axonal bundles (data not shown). The data were analyzed with the unpaired $t$ test.

Experiments with conditioned media. Conditioned media were recovered from the tectal cultures with no retinal explants at 4 and $8 \mathrm{~d}$, and centrifuged twice at $150,000 \times \mathrm{g}$ for $10 \mathrm{~min}$ at $4^{\circ} \mathrm{C}$ to remove cell membranes. Western blot analyses of the conditioned media were performed with monoclonal antibodies specific for ephrin-A2 and ephrinA5. For the conditioned media experiments, they were concentrated with Centrisart I microconcentrators (5 kDa exclusion limit; Sartorius, Goettingen, Germany), and brought to the original volume with F12 minimum medium (F12 nutrient mixture and $2 \mathrm{~mm}$ L-glutamine). For heat inactivation, medium conditioned by the E7 posterior tectal cells for $8 \mathrm{~d}$ was heated to $63^{\circ} \mathrm{C}$ for $8 \mathrm{~min}$ after being concentrated, and it was brought to the original volume with F12 minimum medium. Culture supernatants containing soluble Eph ligands, ephrin-A2-AP or ephrin-A5-AP, were concentrated, and their concentrations were adjusted to 10,20 , or $40 \mathrm{nM}$ by the addition of the medium conditioned by the anterior tectal cells.

Retinal explants $(0.3 \times 0.6 \mathrm{~mm})$ were taken from numbers 4,5 , and 6 of nasal or temporal retinal strips and cultured for $24 \mathrm{hr}$ in $300 \mu \mathrm{l}$ of the conditioned media or the media with the soluble Eph ligands on Matrigel-coated plastic dishes. The cultures were fixed and stained immunofluorescently with the anti-G4/NgCAM antibody. The explants were photographed with a $5 \times$ objective lens, and the images were digitized with the film scanner. By using the National Institutes of Health image software, pixels over axonal bundles were counted, but those over the explant itself or migrated cells were neglected, and the total areas covered with the axonal bundles were calculated $\left(\mathrm{mm}^{2}\right)$. The data were analyzed with the unpaired $t$ test.

The collapse assay was also performed with the conditioned media (Cox et al., 1990). The conditioned media were recovered, centrifuged, and concentrated twofold with the microconcentrators. Fifty microliters of the concentrated conditioned media were added on the retinal explant cultures. They were incubated further for $30 \mathrm{~min}$, fixed with $4 \%$ PFA 

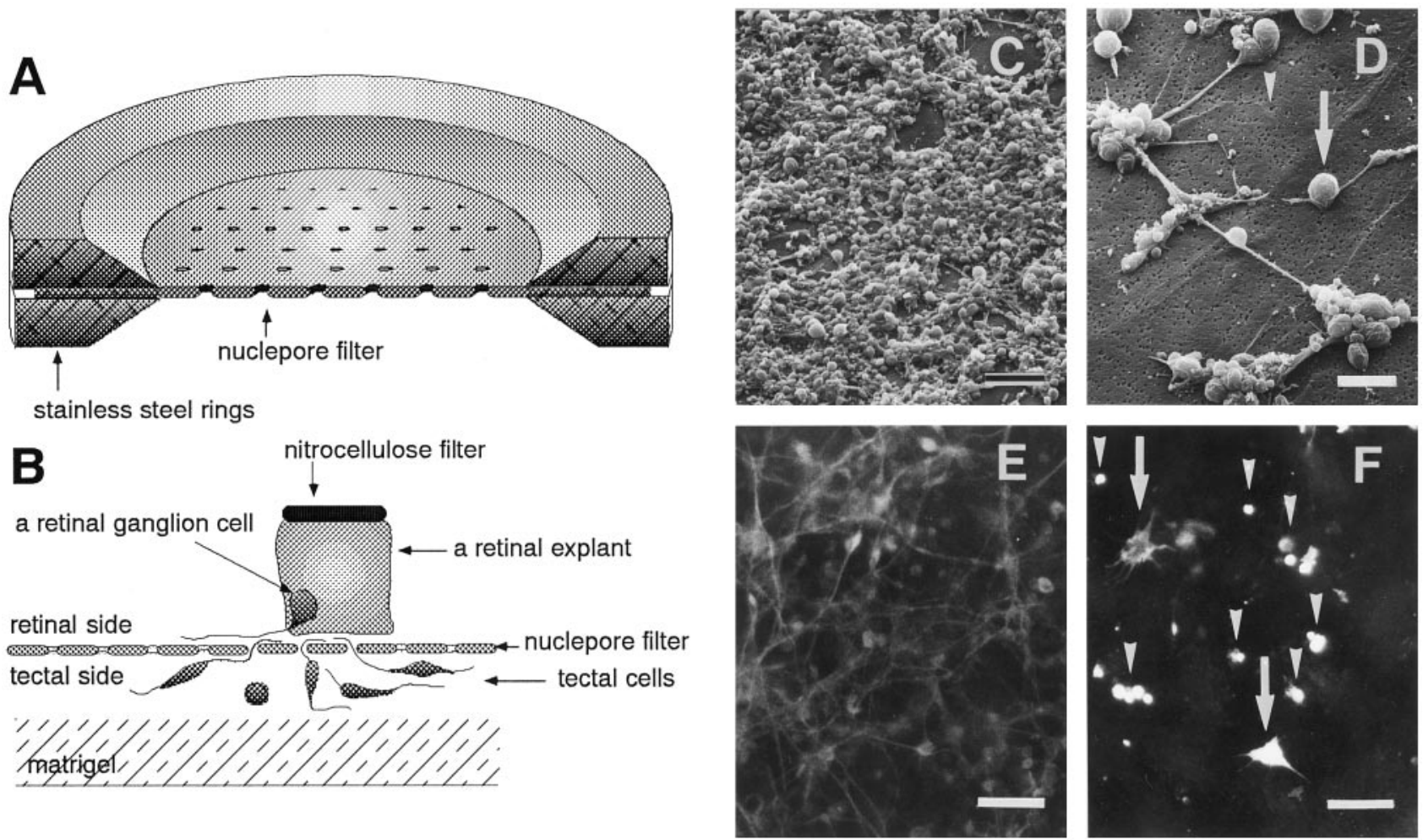

Figure 1. Schematic drawings of the experimental design. $A$, The ryomen chamber consists of a pair of stainless steel rings and a Nuclepore filter. $B$, RGC axons grow on tectal cell processes that have penetrated the filter. $C, D$, Scanning electronmicrographs of the substrates on the retinal side of the filter at $(C)$ low and $(D)$ high magnifications. In $D$, round processes (arrow) and filter pores (arrowhead) are shown. Immunofluorescent staining of the substrates $(5 \mathrm{~d}$ in vitro) by anti-MAP2 $(E)$ and anti-vimentin $(F)$ antibodies. Most of the round processes $(\operatorname{arrowheads}$ in $F)$ and some flat processes with thin spikes (arrows in $F$ ) are labeled by the anti-vimentin antibody. Scale bars: $C, 30 \mu \mathrm{m} ; D, 10 \mu \mathrm{m} ; E, F, 25 \mu \mathrm{m}$.

overnight, and stained in SyproOrange solution (5000× dilution in PBS) (Molecular Probes, Eugene, OR) for $30 \mathrm{~min}$ at room temperature. Under the fluorescence microscope, the numbers of collapsed and noncollapsed growth cones were counted, and the percentages of the collapsed growth cones were calculated. The data were analyzed with the unpaired $t$ test.

Mapping nasotemporal transitions in the retina. To avoid contaminating nasal explants with temporal tissue and vice versa, the most central retinal strip including the optic fissure was discarded, and the explants were taken only from the ventral part adjacent to the optic fissure. The serial explants were cultured on tectal substrates made of cells from one-third or one-sixth of the posterior tecta. They were incubated for $7 \mathrm{~d}$ on the overnight preculture schedule. The explants were also cultured for $2 \mathrm{~d}$ on the alternate membrane carpets in the normal stripe assay as described in Walter et al. (1987a). In the stripe assay, the degree of preference was evaluated according to Walter et al. (1987a).

\section{RESULTS}

\section{Tectal cells cultured in the ryomen chamber differentiate appropriately according to their position of origin}

In the ryomen chamber (Fig. $1 A, B$ ), cells from the anterior or posterior thirds of optic tecta from E7 chicks were cultured overnight on one side of a Nuclepore filter (the tectal side). The next day, the chamber was turned upside down. Processes from the tectal cells penetrated the filter to generate a substrate of tectal cellular membranes on the side of the filter opposite to the tectal cell bodies (the retinal side) (Fig. 1C) (cf. Sariola et al., 1989). This tectal substrate consisted of two types of cell processes: thin-elongated and round (Fig. 1D). The round processes were $\sim 10 \mu \mathrm{m}$ in diameter.

We examined immunohistochemically the expressions of the following cell-type markers: MAP2 for neuronal dendrites (Fig.
$1 E$ ), G4/NgCAM for axons (data not shown), GFAP for mature astrocytic processes (data not shown), and vimentin for immature glial processes $($ Fig. $1 F$ ). The thin, elongated processes in both the anterior and posterior substrates were mainly neuronal, based on MAP2 and G4/NgCAM immunoreactivity. The round processes and some of the thin processes showed vimentin immunoreactivity. No process was immunoreactive for GFAP. The results showed the presence of both neuronal and immature glial processes in the substrates after $5 \mathrm{~d}$ in vitro.

In the developing chick visual system, EphA3 ligands, ephrin-A2 and ephrin-A5, are expressed as gradients with increasing concentrations toward the posterior tectum between E6 and E11. The gradient of ephrin-A5 expression is steeper and confined more to the posterior tectum than that of ephrin-A2. At later stages of development, their expressions are gradually downregulated (Monschau et al., 1997). As a positional and differentiation marker, we examined expression of the EphA3 ligands with an EphA3-alkaline phosphatase fusion protein (EphA3-AP) (Cheng et al., 1995; Drescher et al., 1995). On the tectal side of the filter, cells strongly expressing the EphA3 ligands were seen in the culture of E7 posterior tectal cells by the fourth day (Fig. 2A). In some cases, the round processes were stained on the retinal side (Fig. $2 A$, inset), although heat treatment during the labeling procedure destroyed most of the delicate structure. By the eighth day, the EphA3 ligands were downregulated in the culture of E7 posterior tectal cells as is seen in vivo; the expression on the cells became weaker (Fig. 2B). In contrast, the positive cells were not detected in any cultures of anterior tectal cells (data not shown). 


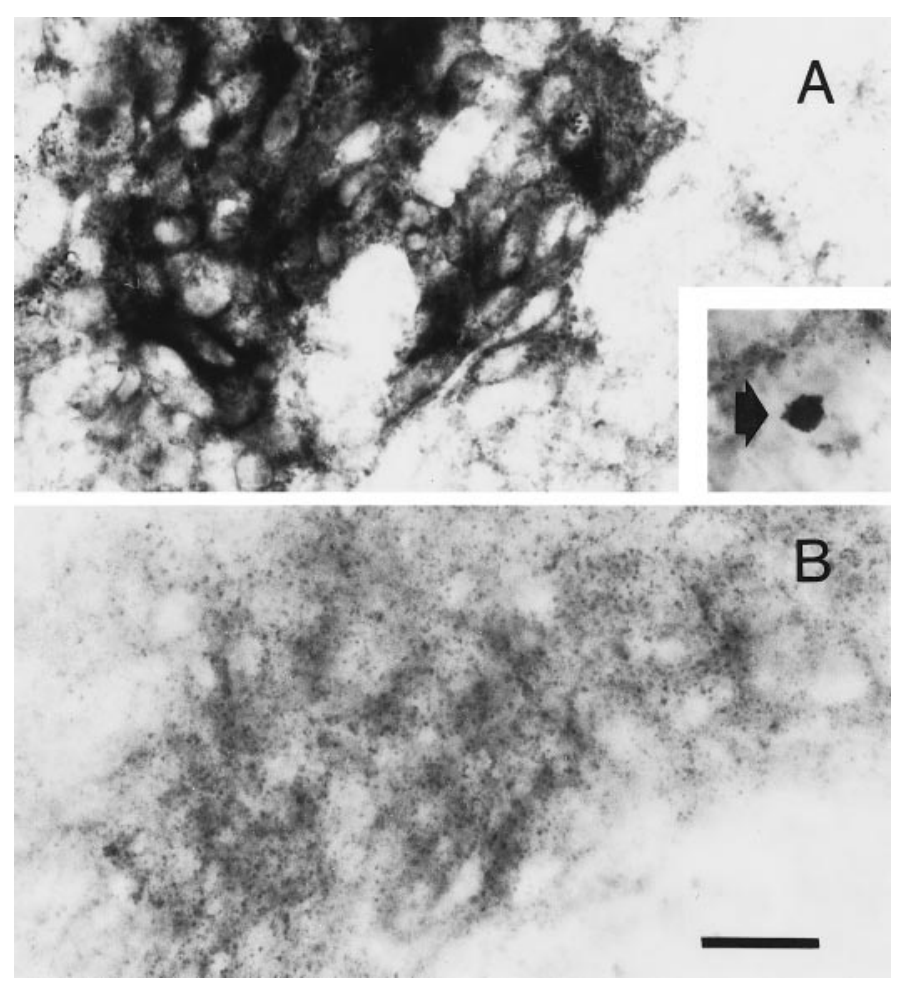

Figure 2. Expression of EphA3 ligands with RAP in situ histochemistry. EphA3 ligands are expressed by the posterior tectal cells on the tectal side of the filter intensely after $4 \mathrm{~d}(A)$ and weakly after $8 \mathrm{~d}(B)$ in vitro. A round process on the retinal side (arrow) is labeled by EphA3-AP (inset in A). Scale bar, $25 \mu \mathrm{m}$.

\section{Withdrawal of temporal retinal axons from a posterior tectal substrate}

Retinal explants were prepared from specific regions of E6 nasal or temporal retina (see Materials and Methods) and were placed on the retinal side (Fig. $1 A, B$ ). Up to the third day of retinal culture (see Fig. 5A, Experimental Schedule), axons from nasal and temporal retinae grew well on both the anterior and posterior substrates (Fig. $3 A-D$ ), except that the temporal axons tended to be more fasciculated on the posterior substrates. By the seventh day, however, most of the temporal axons withdrew from the posterior substrates. The remaining axons were short and highly fasciculated (Fig. 3H). In contrast, the temporal axons did not withdraw from the anterior substrates. The nasal axons grew well and were largely maintained on both substrates, although the number of axon bundles gradually decreased by the seventh day (Fig. 3E-G).

To examine whether the withdrawal of temporal axons is regulated by differentiation of the tectal cells in vitro, we placed the temporal explants on the posterior substrates precultured for $4 \mathrm{~d}$. In this long preculture schedule, the temporal axons initially grew poorly by the third day of retinal culture (Fig. 4D) and subsequently grew by the seventh day (Fig. 4H). In all of the other axon/substrate combinations, axons grew profusely up to the third day of retinal culture and were maintained by the seventh day: the nasal axons on the anterior long precultured tectal cells (Fig. $4 A, E$ ) and on the posterior long precultured tectal cells (Fig. $4 B, F)$, and the temporal axons on the anterior long precultured tectal cells (Fig. 4C,G).

To quantify the axon withdrawal, we measured the maximum densities of axonal bundles in each axon/substrate combination.
The densities of temporal bundles were reduced on the E7 posterior substrates cultured for 7 or $8 \mathrm{~d}$, regardless of how long they had been precultured (the standard overnight preculture schedule or the long preculture schedule for $4 \mathrm{~d}$ ) (Fig. 5). In the standard schedule, the densities of temporal bundles decreased significantly $(p<0.01)$ to $53 \%$ from the fourth day $\left(0.28 \mathrm{~mm}^{2} / \mathrm{mm}^{2}\right.$, $n=10)$ to the eighth day $\left(0.15 \mathrm{~mm}^{2} / \mathrm{mm}^{2}, n=10\right)$. In the long preculture schedule, the density was low at the seventh day $(0.15$ $\left.\mathrm{mm}^{2} / \mathrm{mm}^{2}, n=10\right)$, and thereafter it increased by the 11 th day $\left(0.27 \mathrm{~mm}^{2} / \mathrm{mm}^{2}, n=10\right)$. In contrast, the densities of temporal bundles remained high throughout the incubation period on the anterior substrates; those of nasal bundles remained high throughout the incubation period on both substrates. A decrease of the nasal bundle densities was not significant on the posterior substrates that were precultured overnight $(p>0.05)$.

\section{A factor in the conditioned medium inhibits outgrowth of temporal axons}

To characterize the axonal withdrawal seen in the ryomen assay, we cultured retinal explants in media conditioned by the tectal cells growing in the ryomen chambers. Because the crude conditioned media contained low molecular weight metabolites that might nonspecifically inhibit axon outgrowth, the media were freed of low molecular weight components with Centrisart I microconcentrators (5 kDa exclusion limit; Sartorius), and they were subsequently brought up to the original volumes with the F12 minimum medium. In media conditioned by the E7 posterior tectal cells for $8 \mathrm{~d}$, the temporal axons did not grow well, although the nasal axons grew profusely (Fig. 6A,B). The temporal axon outgrowth was $60 \%$ of the nasal axon outgrowth with respect to total area covered with axonal bundles from an explant [temporal, $0.15 \mathrm{~mm}^{2}(n=20)$; nasal, $0.25 \mathrm{~mm}^{2}(n=20) ; p=0.0033$ ] (Fig. $6 D)$. When this conditioned medium was heat-treated, the nasal and temporal axons grew equally well (Fig. $6 C, D$ ). In contrast, both nasal and temporal axons grew well in media conditioned by E7 anterior tectal cells for 4 and $8 \mathrm{~d}$, and by the E7 posterior tectal cells for $4 \mathrm{~d}$ (Fig. 6D). Additionally, to determine whether the collapse of temporal growth cones is induced by the conditioned media, the collapse assay was performed. But similar percentages of collapses were induced between the nasal and temporal growth cones $[30 \%(\mathrm{SE}=4 \%, n=18)$ and $37 \%(\mathrm{SE}=$ $4 \%, n=18)$, respectively; $p>0.05$ ] by the medium conditioned by the E7 posterior tectal cells for $8 \mathrm{~d}$.

To exclude the possibility that release of glycosylphosphatidylinositol (GPI)-anchored Eph-ligands, ephrin-A2 and -A5, from tectal cell membranes generated the soluble withdrawal-inducing factor, Western blot analyses were performed with a monoclonal antibody specific for ephrin-A2 or -A5. Neither of the ephrins was detected in the media conditioned by E7 posterior tectal cells for $8 \mathrm{~d}$ (their detection limits were $\sim 17 \mathrm{~nm}$ for ephrin-A2 and $30 \mathrm{~nm}$ for ephrin-A5). Furthermore, retinal explants were cultured with the soluble monovalent ephrin-A2 or ephrin-A5 diluted with the medium conditioned by the anterior tectal cells for $4 \mathrm{~d}(4 \mathrm{~A})$, but nasal and temporal axons grew equally in 10, 20, or $40 \mathrm{~nm}$ ephrin-A2 or ephrin-A5 (data for $20 \mathrm{~nm}$ shown in Fig. 6D).

\section{The retinal sensitivity to the axonal withdrawal is graded along the nasotemporal axis}

To characterize the possible function of the axonal withdrawal, we mapped more precisely the retinal response to the posterior substrates. Tissue strips (300- $\mu \mathrm{m}$-width) were cut serially from nasal to temporal sides of the retina. The explants were numbered 
3 days in culture

Nasal/Anterior

Nasal/Posterior

Temporal/Anterior

Temporal/Posterior
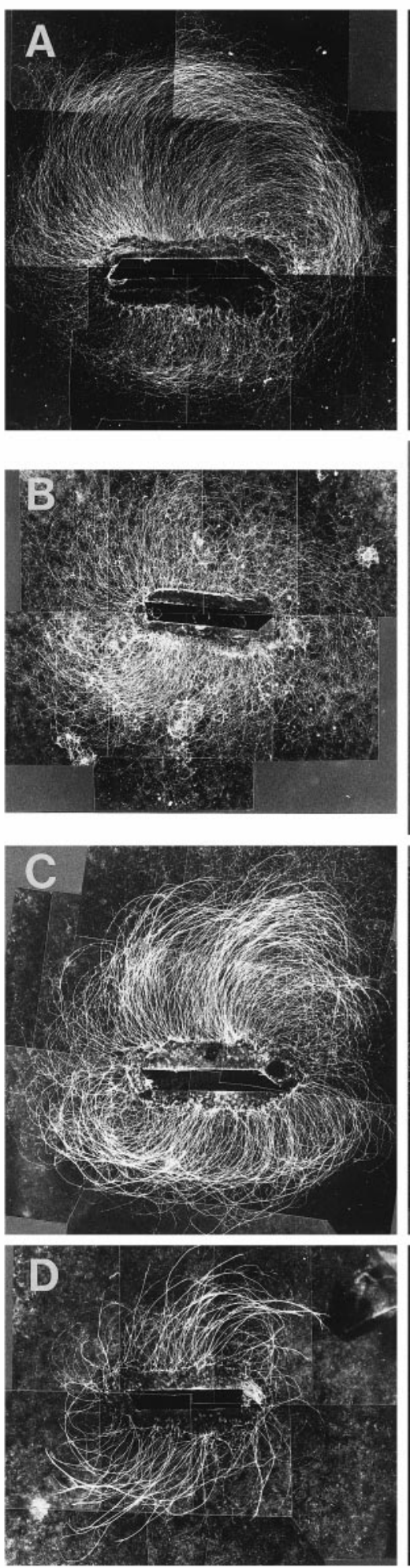
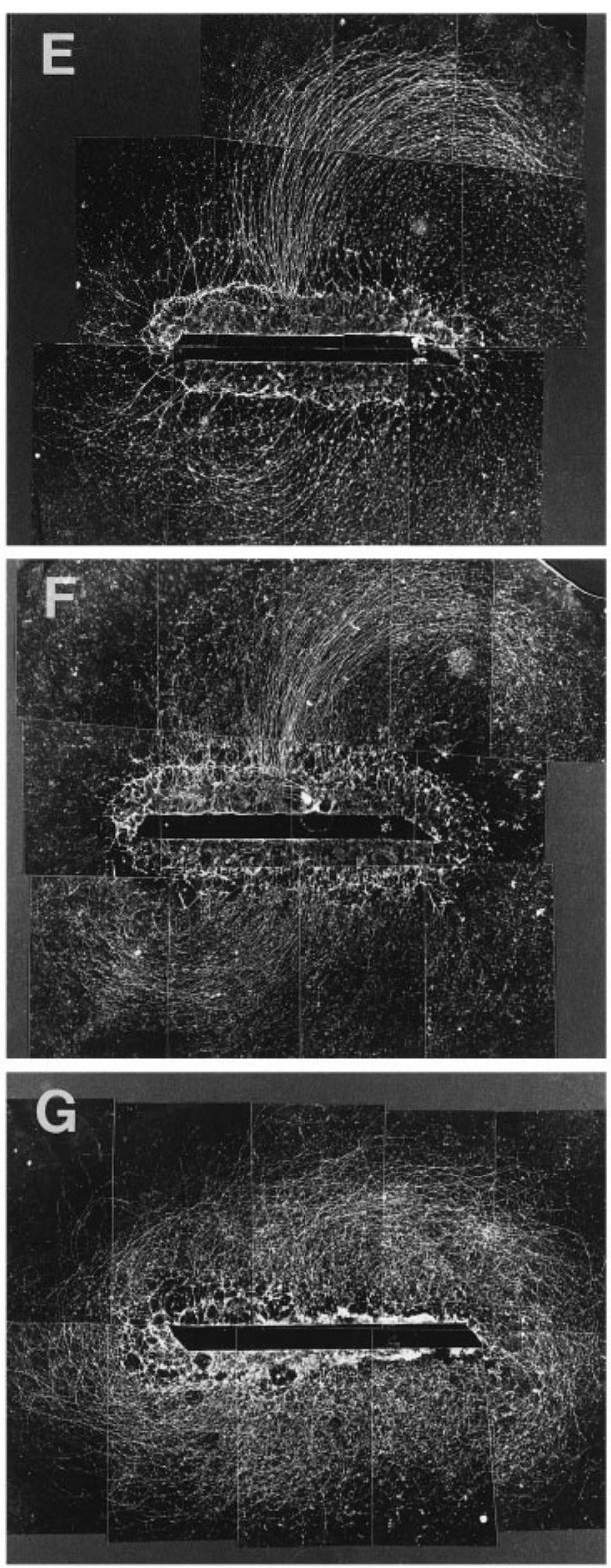

7 days in culture

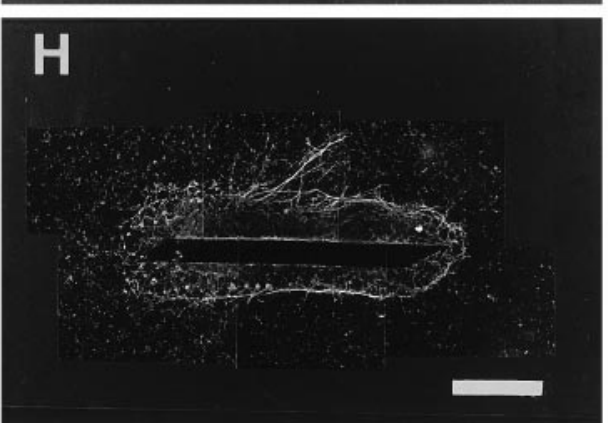

Figure 3. Growth of retinal axons in the standard overnight preculture schedule. $A-D$, Views of the axons from the retinal side of the filter after $3 \mathrm{~d}$. The axons grow well on both the anterior and posterior substrates. Black areas in the middle of the pictures are the nitrocellulose filters mechanically supporting the retinal tissues. The nasal axons on the anterior $(A)$ and posterior $(B)$ substrates. The temporal axons on the anterior $(C)$ and posterior $(D)$ substrates. $E-H$, Views of the axons after 7 d. The temporal axons remain on the anterior substrate $(G)$, but most of them do not stay on the posterior substrate $(H)$. The nasal axons remain on the anterior $(E)$ and posterior $(F)$ substrates. Axon-substrate combinations are also shown at the left side of pictures. Scale bar, $1 \mathrm{~mm}$. 
3 days in culture
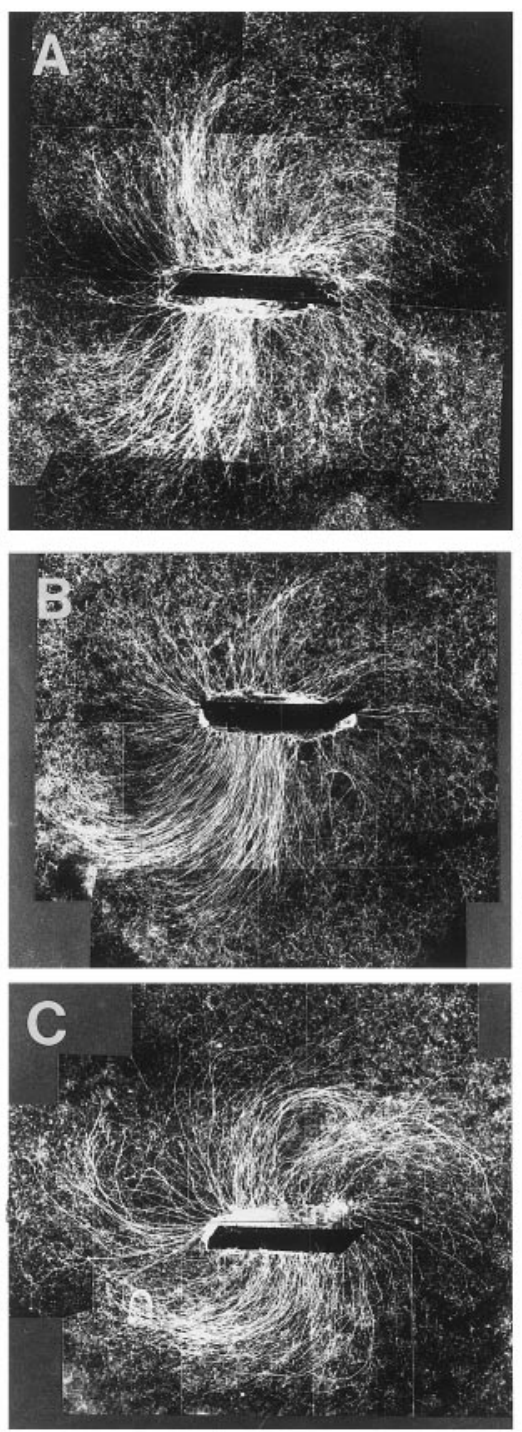

Temporal/Anterior*

Temporal/Posterior*

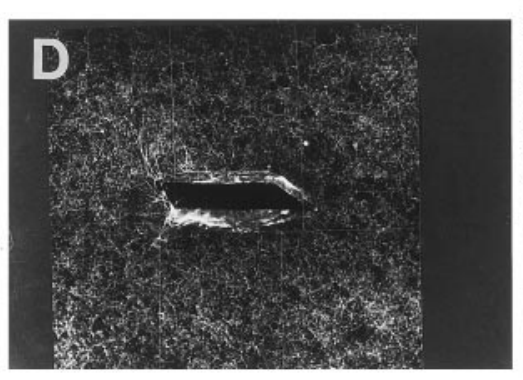

\section{7 days in culture}
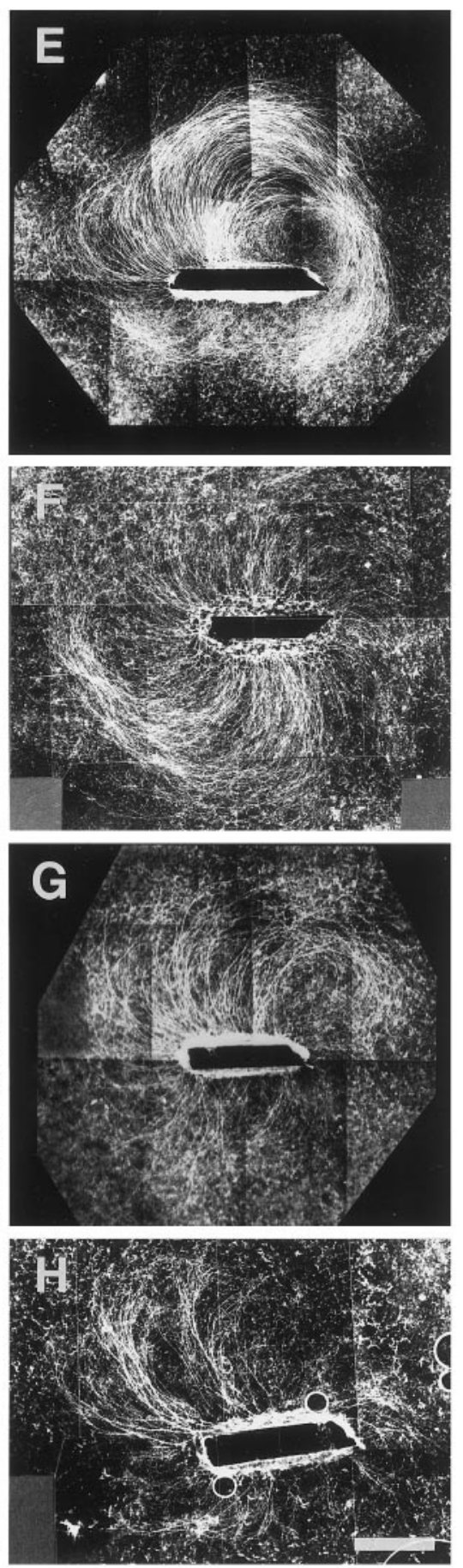

Figure 4. Growth of retinal axons in the long preculture schedule for $4 \mathrm{~d}$ (see Fig. $5 A$ ). $A-D$, The axons after 3 d. The temporal axons grow on the anterior substrate $(C)$ but do not grow on the posterior substrate $(D)$. The nasal axons grow on both the anterior $(A)$ and posterior $(B)$ substrates. $E-H$, The axons after $7 \mathrm{~d}$. The temporal axons recover to grow on the posterior substrate $(H)$, and they remain on the anterior substrate $(G)$. The nasal axons remain on both the anterior $(E)$ and posterior $(F)$ substrates. Axon-substrate combinations are also shown at the left side of pictures. Anterior* and Posterior* indicate the anterior and posterior substrates precultured for $4 \mathrm{~d}$, respectively. Scale bar, $1 \mathrm{~mm}$.

from the center to the periphery (Fig. $7 A$ ) and cultured for $7 \mathrm{~d}$ on the substrates derived from posterior tectal fragments (one-third or one-sixth) that had been precultured overnight.

On the substrates consisting of the posterior third of the tectum, the nasotemporal transition of the withdrawal response was continuous, and nasal retinae varied in their responses gradually from the center to the periphery. From the first nasal explants, containing the nasal tissue from 0 to $300 \mu \mathrm{m}$ adjacent to the optic fissure, the axons withdrew as temporal axons did. From the second nasal explants, containing the tissue from 300 to $600 \mu \mathrm{m}$, 


\section{(A) Experimental Schedule}

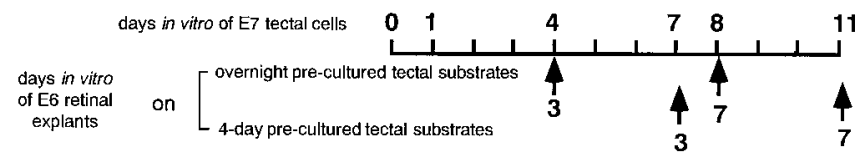

(B) Nasal Retina

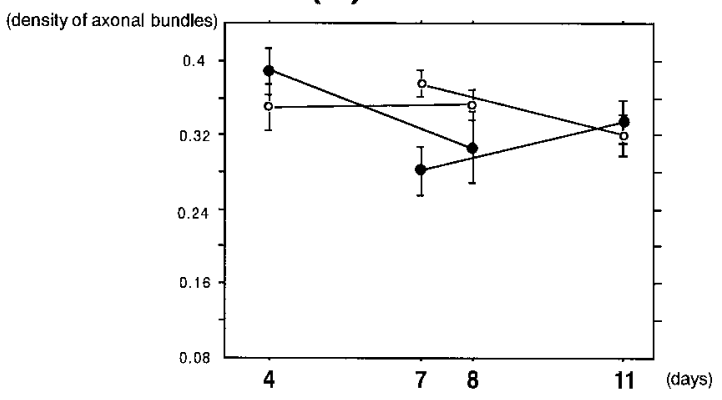

(C) Temporal Retina

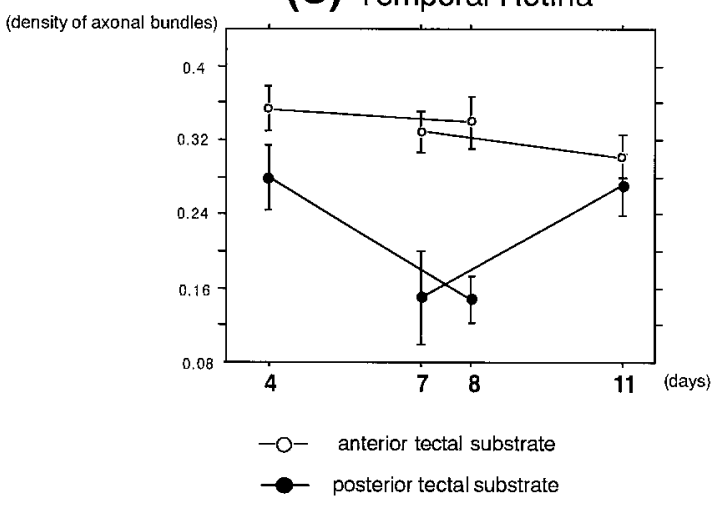

Figure 5. The experimental schedule is shown in $A$. Retinal explants are added at day 1 (the standard overnight preculture schedule) or day 4 (the long preculture schedule) in vitro of the tectal cells. The explants are incubated for an additional 3 or $7 \mathrm{~d}$. Maximum densities of nasal $(B)$ and temporal $(C)$ axonal bundles are shown as a function of days in vitro for the tectal cells. The densities of the temporal bundles are reduced on the posterior substrates at the seventh and eighth day. Open and closed circles indicate the densities of axonal bundles on the anterior and posterior substrates, respectively. SEs are shown. $n=10$ for each condition.

the axons withdrew partially. From the third nasal explants, containing the tissue from 600 to $900 \mu \mathrm{m}$, the axons remained on the posterior tectal substrates as the peripheral nasal axons did (Fig. 7D). Quantitative analyses confirmed the gradual response of the retinae to the substrates. The boundary between the responsive temporal and partially responsive nasal retina was not located at the optic fissure but was displaced nasally by $\sim 300 \mu \mathrm{m}$ (Fig. $7 B$ ). On the substrates consisting of the posterior sixth of the tectum, the axons from more nasal explants, for example the fourth or fifth nasal explants, withdrew, and the boundary between the responsive and partially responsive retina shifted nasally (Fig. $7 B$ ).

We used the serial explantation of retinae in the stripe assay. The experiments confirmed that a step transition between nasal and temporal retinal responses to the membrane-bound repulsive factor was located at the optic fissure (Fig. $7 B, C$ ).

\section{DISCUSSION}

To investigate the development of the retinotectal map, we devised the ryomen chamber assay, examined the long-term interactions of retinal axons and tectal neurites, and found that the withdrawal of retinal axons was induced in vitro by a diffusible factor from the posterior tectal cells. Because the effect on axonal withdrawal appeared later than the expression of ephrin-A2 and -A5, it might be involved in the late stage of the map development.

\section{Advantages and limitations of the ryomen chamber assay}

In the ryomen chamber, tectal substrates consisted of various cellular processes, including neuronal and immature glial processes, but no mature glial processes (Fig. 1), which is consistent with the presence of vimentin-positive immature glia and the absence of GFAP-positive mature glia in the developing tectum in vivo (Vanselow et al., 1989; Herman et al., 1993). Moreover, the EphA3 ligands were expressed in the posterior tectal substrates, but not in the anterior substrates, on the fourth day in culture. Their expression in the posterior substrate was downregulated on the eighth day (Fig. 2). Because the expression pattern of the EphA3 ligands was spatially and temporally similar to their pattern in vivo, the substrates were likely to retain their original topographic characters and differentiate in vitro, at least as far as we have assayed. Furthermore, because the substrates consisted of living cell processes, they offered an environment to the retinal axons simultaneously through both direct contact and diffusion. In contrast to the ryomen chamber assay, it was difficult to keep tectal tissue viable for $7 \mathrm{~d}$ without a sufficient supply of gases and nutrients in the organotypic cultures $(\mathrm{H}$. Ichijo, unpublished observation), and it was difficult to keep tectal neurons from aggregating, to prevent GFAP-positive glial cells from proliferating, and to keep the cultures intact for more than $5 \mathrm{~d}$ in the simple conventional monolayer cultures (H. Ichijo, unpublished data). Thus, the substrates in the ryomen chamber seem to mimic the in vivo situation more closely than those in the conventional cultures. This might be because the tectal cells are packed between a filter and a gel matrix at a high density [approximately seven cells/(10 $\mu \mathrm{m})^{2}$ ] with a sufficient supply of gases, which allows them to interact locally with each other.

The ryomen chamber assay also has limitations. (1) It is known that molecules affecting axonal growth are distributed in specific laminae of the tectum (Yamagata et al., 1995). Because the multilayered tectum is dissociated, the lamina-specific cues are not kept intact, but a mixture of them is believed to be present in the substrate. Despite this limitation, the substrates preserved some characters of the developing tectum as we have described above. (2) In addition, it is rather difficult to investigate axonal behavior directly in the ryomen chamber, for example, real-time or time-lapse observation, because of the opaque Nuclepore filter.

\section{A diffusible factor induces withdrawal of retinal axons}

In the standard overnight preculture schedule, the temporal axons withdrew from the substrate made of posterior tectal cells, which are not their in vivo targets. The density of temporal axons decreased by the seventh day on the posterior substrate (Fig. 3), which seemed to be controlled in a region-specific way like in vivo.

To examine whether the axonal withdrawal is regulated by in vitro differentiation of tectal cells, we placed the explants on the posterior substrates precultured for $4 \mathrm{~d}$. In this long preculture schedule, the temporal axons grew poorly by the third day (Fig. 

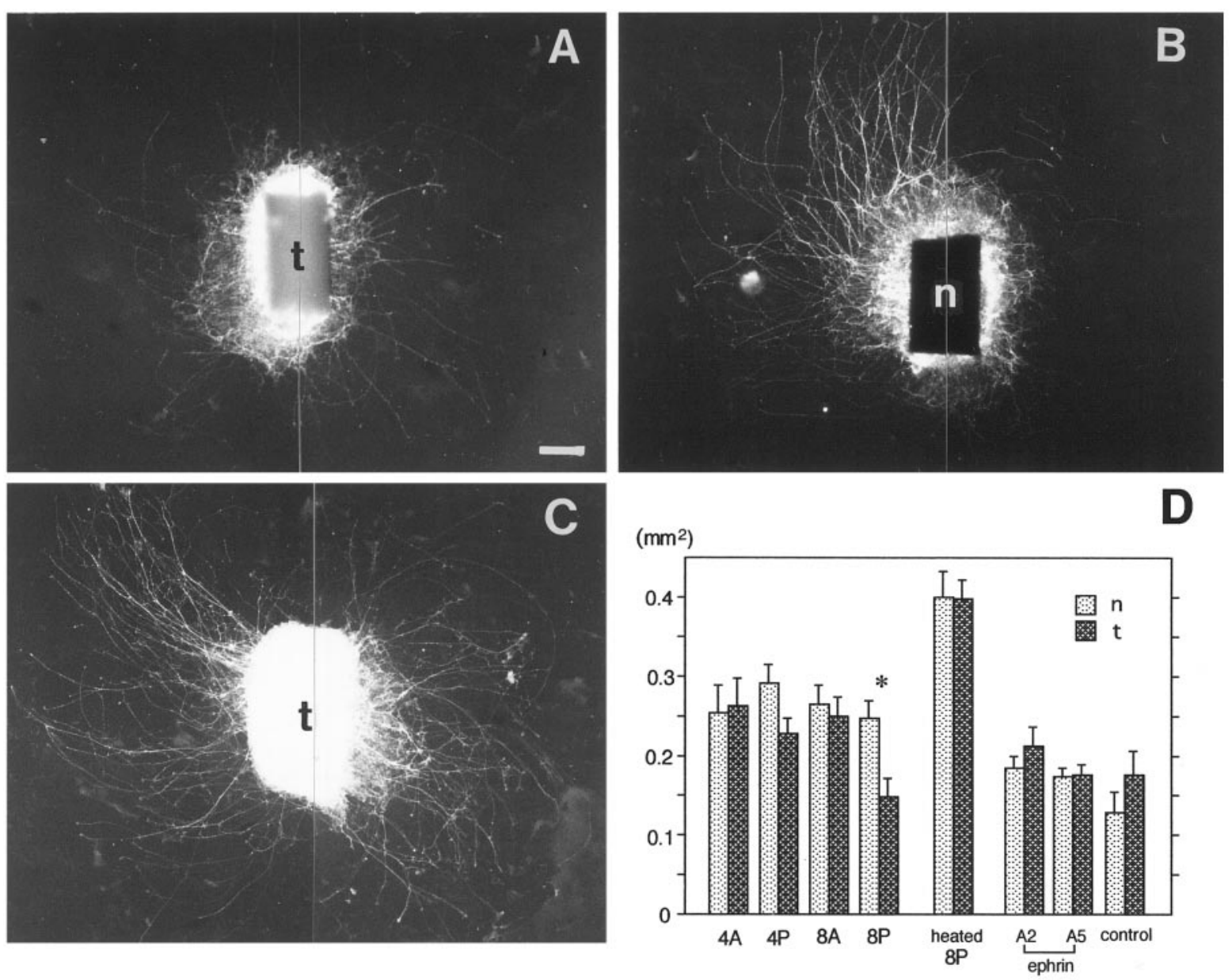

Figure 6. Growth of retinal axons in the conditioned media. Nasal and temporal explants are indicated as $n$ and $t$, respectively. Temporal $(A)$ and nasal $(B)$ explants are cultured in the medium conditioned for $8 \mathrm{~d}$ by the $\mathrm{E} 7$ posterior tectal cells. $C$, A temporal explant is cultured in heat-treated medium conditioned for $8 \mathrm{~d}$ by the E7 posterior tectal cells. Scale bar, $200 \mu \mathrm{m}$. D, Axonal outgrowth from the nasal and temporal explants in the conditioned media or in the presence of the soluble ephrins. Light gray and dark gray bars indicate amounts of the nasal and temporal outgrowth (the total areas covered with the axonal bundles from an explant), respectively. $4 A$ and $8 A$ indicate the axonal outgrowth in media conditioned by the E7 anterior tectal cells for 4 and $8 \mathrm{~d}$, respectively. $4 P$ and $8 P$ indicate the axonal outgrowth in media conditioned by the $\mathrm{E} 7$ posterior tectal cells for 4 and $8 \mathrm{~d}$, respectively. Heated $8 P$ indicates the axonal outgrowth in heat-treated medium that was conditioned by the E7 posterior tectal cells for 8 d. $n$ is between 12 and 22 for each condition. ephrin $A 2$ and $A 5$ indicate the axonal outgrowth in the media conditioned by the E7 anterior tectal cells for $8 \mathrm{~d}$ with 20 nM ephrin-A2-AP and ephrin-A5-AP, respectively. control indicates the axonal outgrowth in the F12 minimum medium. $n$ is between 5 and 10 for each condition. The difference between the nasal and temporal outgrowth is significant in $8 P(p=0.0033$, indicated by $*)$ but not in $4 P(p>0.05)$.

$4 D)$ and subsequently recovered to grow well by the seventh day (Fig. 4H). The density of temporal axons was reduced at a particular stage of the posterior substrate cultured for 7 or $8 \mathrm{~d}$ (Fig. 5). At this stage, after the EphA3 ligands had already been downregulated, a heat-labile factor secreted by the posterior tectal cells inhibited the outgrowth of retinal axons differentially; it inhibited the outgrowth of the temporal axons (Fig. 6). Accumulation of the factor in the culture medium might be responsible for the withdrawal of temporal axons in the standard preculture experiments, and its gradual reduction might cause the delayed outgrowth of temporal axons in the long preculture experiments.

In addition, the recovery of growth took place in relatively old retinal tissue in which RGCs are unlikely to be generated, although in vivo RGCs are born between E2 and E8 (Snow and Robson, 1994). The withdrawal might be attributable to direct effects on the axons rather than to cell death. We performed the collapse assay with the conditioned media but did not detect collapse-inducing activity in the medium conditioned by E7 posterior tectal cells for $8 \mathrm{~d}(8 \mathrm{P})$ in which the growth of the temporal axons was inhibited in the outgrowth assay. It seems likely that the collapse assay is not sensitive enough to detect the activity in the conditioned medium, although it cannot be excluded that the collapse of temporal growth cones is not induced by the withdrawal-inducing factor.

By using the serial explantation of retinae, it was shown that the nasal axons partially withdrew from the substrates made of extremely posterior tectal cells as the temporal axons did (Fig. 7B). It is thought that (1) production of the factor increased toward the posterior pole of the tectum, and (2) a higher concentration of the factor induced the withdrawal of nasal axons as well as temporal axons. Outgrowth of the nasal axons also seems to be inhibited to some extent in the conditioned medium, $8 \mathrm{P}$, because either temporal or nasal axons grew robustly in the heated $8 \mathrm{P}$ (Fig. $6 D$ ). The temporal and nasal axons might be released from the inhibition by inactivation of the factor with the heat treatment.

Ephrin-A2 and -A5 were characterized previously as retinotectal repulsive factors. They are expressed topographically in the tectum with gradients that increase toward its posterior pole and 


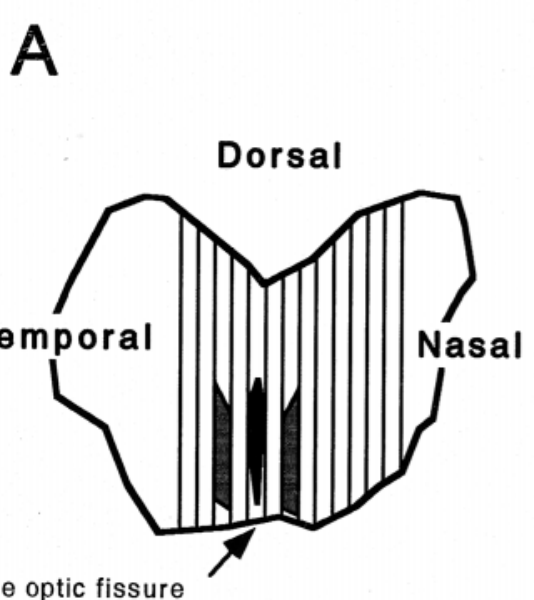

Ventral
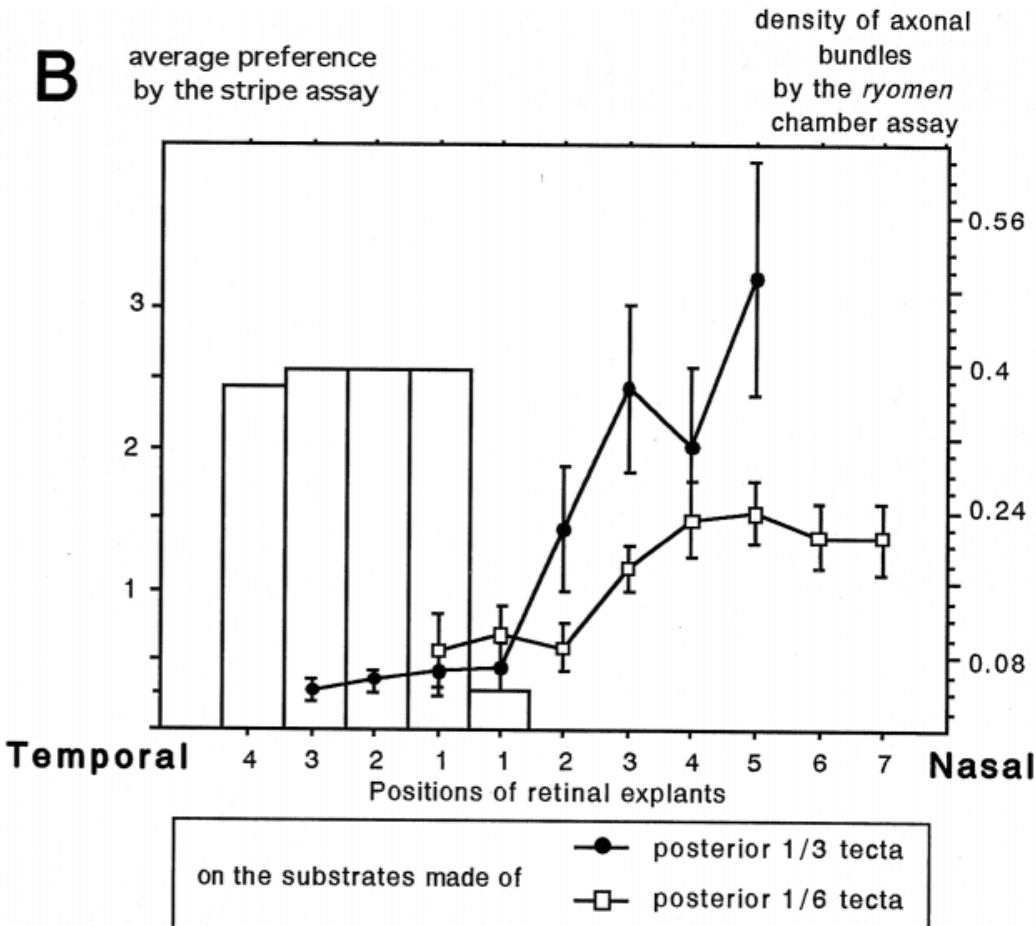

\section{Temporal}
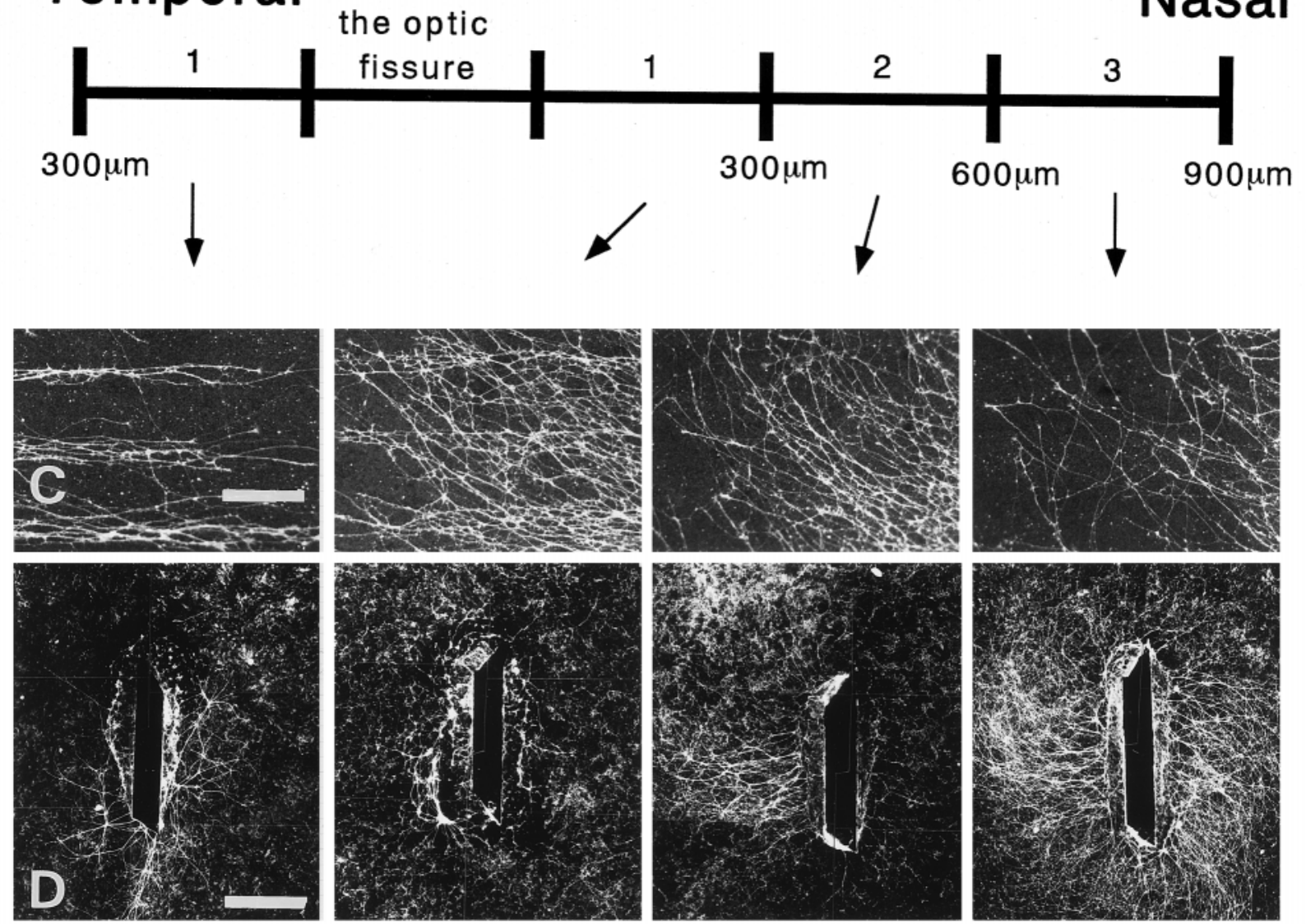

Figure 7. Mapping nasotemporal transitions in retinae with the stripe assay and the ryomen chamber assays. $A$, Original positions of the retinal explants are shown. $B$, Average preferences of the retinal axons in the stripe assay as white bars (the left ordinate), maximum densities in the ryomen chamber assay (the right ordinate) on the substrates made from the posterior third of the tecta (closed circles) and on the substrates made from the posterior sixth of the tecta (open squares). The explants are represented at their original positions in the retinae (the abscissa). A steep slope of transition from the center to the periphery in the nasal retina is seen on the substrate made from the posterior third of the tecta, and a gradual slope on the (Figure legend continues). 
repel temporal retinal axons (Walter et al., 1987a,b; Cheng et al., 1995; Drescher et al., 1995; Nakamoto et al., 1996; Monschau et al., 1997). Although the withdrawal-inducing factor and the ephrins have some common properties, they seem to be different factors. (1) The withdrawal-inducing factor was secreted into the medium, whereas ephrin-A2 and -A5 were linked to cell membranes by a GPI-anchor. (2) Because ephrin-A2 and -A5 were not detected in the conditioned media, they do not seem to be cleaved significantly from the cell membranes. (3) Neither of the soluble monovalent ephrins had a differential effect on the growth of nasal and temporal axons (Fig. 6D). The amounts of axonal outgrowth were slightly less in media with the soluble ephrins than those in the media conditioned by the tectal cells (Fig. 6D). Because the soluble ephrins were produced by the COS cells and recovered as the medium supernatants, the media with the ephrins could consist of different ingredients from the media conditioned by the tectal cells (Monschau et al., 1997). Thus, it is difficult to compare simply the absolute values of the outgrowth in the media containing the ephrins with those in the media conditioned by the tectal cells. (4) The withdrawal effect was seen late after the EphA3 ligands were already downregulated but never correlated with their expression (Fig. 2). Because it is known that membrane attachment of Eph-ligands or their artificial clustering is essential for receptor activation (Davis et al., 1994), it is unlikely that the soluble withdrawal-inducing factor was generated simply by the release of the monovalent ephrins from the cell membranes, but an additional factor seems to be required. There are two possibilities. First, the withdrawal-inducing factor has a direct and distinct effect on RGC axons and is expressed after the downregulation of the ephrins. Second, the withdrawal-inducing factor causes the axonal withdrawal indirectly through binding to the released ephrins and forming their multivalent complexes.

Another activity involved in the map formation was reported by von Boxberg et al. (1993). This activity, the survival-promoting activity, contrasts clearly with the withdrawal-inducing factor. (1) The survival-promoting activity is associated with the posterior tectal membranes, (2) it is expressed during the middle stage of the map development (E10-12), and (3) it does not affect the temporal axons but affects the nasal axons by promoting their survival. Thus, the survival-promoting activity and the withdrawal-inducing factor appear to be distinct.

\section{The axonal withdrawal and its possible involvement in the development of the retinotectal map}

The development of the retinotectal map has two stages in mammals and birds (Nakamura and O'Leary, 1989; Simon and O'Leary, 1992; Mark et al., 1993). In the chick, axons grow first in part even beyond their appropriate terminal zone; thus, the result is a crude projection. Ephrin-A2 and -A5 are expressed during the initial stage. Ephrin-A2 could serve to keep specifically temporal axons from invading the posterior tectum, whereas it could leave nasal axons unaffected, because nasal axons, in contrast to temporal axons, are insensitive to ephrin-A2 (Nakamoto et al., 1996). The expression of ephrin-A5 is confined to the posterior tectum. Transition of the ephrin-A5 sensitivity between nasal and temporal axons appears to be abrupt like the nasotemporal transition of axonal behavior on the usual striped or graded anterior/ posterior tectal membrane carpets (S. Rosentreter, personal communication), although at a low concentration of ephrin-A5 a gradual change of the repulsive response is observed from the center to the periphery within the nasal retina (Monschau et al., 1997). Thus, ephrin-A2 and -A5 might be involved in the formation of the initial projection (nasal to posterior and temporal to anterior). In addition, ephrin-A5 might also be involved in the map formation of nasal axons on the posterior tectum.

Frisén et al. (1998) examined the function of ephrin-A5 by generating the mice lacking ephrin- $A 5$. In these ephrin- $A 5^{-/-}$ mice, many retinal axons aberrantly invaded into the inferior colliculus at the initial stage of the map development (P2); however, their overshooting was subsequently eliminated. In the map finally established (P11), the axons projected to the topographically correct site in the superior colliculus, although they additionally projected to ectopic sites in certain cases. The results suggested the involvement of ephrin-A5 in the initial stage of the map development. Taken together, ephrin-A2 and -A5 do not seem to be necessarily sufficient for generating the continuous topographic map.

There is a controversy, however, about the ephrins and their roles in the map formation. Although the step transition of retinal sensitivity to the ephrins is shown between the nasal and temporal retina in vitro (Walter et al., 1987a,b; Nakamoto et al., 1996; Monschau et al., 1997; Honda, 1998) (Fig. 7), it has not been reported whether such a step transition exists functionally in vivo. The initial map formation in vivo has been described only for temporal axons (Nakamura and O'Leary, 1989), but there is little information about the initial targeting of nasal and central axons. It will be important to investigate the in vivo projection more closely to determine whether the initial projection is crude and continuous or bimodal and discontinuous along the anteroposterior axis on the tectum.

The initial projection is remodeled, thereafter, to a precise topographic map by selective removal of aberrant axons without cell death (Fujisawa, 1987; Williams and McLoon, 1991) and by the selective death of RGCs (McLoon and Lund, 1982; O'Leary et al., 1986). In the present study, the results indicated that (1) the nasotemporal transition of sensitivity to the withdrawal-inducing factor was not abrupt but continuous, (2) the sensitivity decreased gradually from the center to the periphery in the nasal retina, (3) production of the factor seemed to increase toward the posterior pole of the tectum, and (4) the withdrawal effects appeared after the EphA3 ligands were downregulated. These features of the withdrawal-inducing factor are consistent with its contribution to the late stage of map development: for instance, remodeling of the retinotectal map. We propose that the retinal axons are sequentially controlled by membrane-bound repulsive factors (the ephrins) (Walter et al., 1987a,b; Drescher et al., 1995; Cheng et al., 1995; Nakamoto et al., 1996; Monschau et al., 1997) and the diff usible factor (the withdrawal-inducing factor).

In addition, retinal axons were kept for $\sim 1$ week on the appropriate substrates in the ryomen chamber, although it is generally known that the axons degenerate on the laminin-coated coverslip after 3 or $4 \mathrm{~d}$ in the conventional explant cultures. The results suggest that other factors supporting the axonal maintenance 
might exist in the ryomen chamber in addition to the withdrawalinducing factor. In another system, a survival-promoting activity has been shown to be associated with posterior tectal membranes (von Boxberg et al., 1993). Furthermore, activity-dependent synaptic stabilization could fine-tune the map. Therefore, it might be more likely that the final map is established through several mechanisms operating in concert to guide the retinal growth cones to their correct retinotopic positions.

\section{REFERENCES}

Bonhoeffer F, Huf J (1982) In vitro experiments on axon guidance demonstrating an anterior-posterior gradient on the tectum. EMBO J 1:427-431.

Carri NG, Ebendal T (1987) Target-field specificity in the induction of retinal neurite outgrowth. Brain Res 428:83-90.

Cheng H-J, Flanagan JG (1994) Identification and cloning of ELF-1, a developmentally expressed ligand for the Mek4 and Sek receptor tyrosine kinases. Cell 79:157-168.

Cheng H-J, Nakamoto M, Bergemann AD, Flanagan JG (1995) Complementary gradients in expression and binding of ELF-1 and Mek4 in development of the topographic retinotectal projection map. Cell 82:371-381.

Constantine-Paton M, Blum AS, Mendez Otero R, Barnstable CJ (1986) A cell surface molecule distributed in a dorsoventral gradient in the perinatal rat retina. Nature 324:459-462.

Cox EC, Mueller B, Bonhoeffer F (1990) Axonal guidance in the chick visual system: posterior tectal membranes induce collapse of growth cones from the temporal retina. Neuron 4:31-37.

Crossland WJ, Cowan WM, Rogers LA, Kelly JP (1974) The specification of the retinotectal projection in the chick. J Comp Neurol $155: 127-164$.

Davenport RW, Thies E, Nelson PG (1996) Cellular localization of guidance cues in the establishment of retinotectal topography. J Neurosci 16:2074-2085.

Davenport RW, Thies E, Zhou R, Nelson PG (1998) Cellular localization of ephrin-A2, ephrin-A5, and other functional guidance cues underlies retinotopic development across species. J Neurosci 18:975-986.

Davis S, Gale NW, Aldrich TH, Maisonpierre PC, Lhotak V, Pauwon T, Goldfarb M, Yancopoulos GD (1994) Ligands for EPH-related receptor tyrosine kinases require membrane attachment or clustering for activation. Science 266:816-819.

Drescher U, Kremoser C, Handwerker C, Loeschinger J, Noda M, Bonhoeffer F (1995) In vitro guidance of retinal ganglion cell axons by RAGS, a $25 \mathrm{kDa}$ tectal protein related to ligands for Eph receptor tyrosine kinases. Cell 82:359-370.

Easter Jr SS, Stuermer CA (1984) An evaluation of the hypothesis of shifting terminals in the goldfish optic tectum. J Neurosci 4:1052-1063.

Flanagan JG, Leder P (1990) The kit ligand: a cell surface molecule altered in Steel mutant fibroblast. Cell 63:185-194.

Frisén J, Yates PA, McLaughlin T, Friedman GC, O'Leary DDM, Barbacid M (1998) Ephrin-A5 (AL-1/RAGS) is essential for proper retinal axon guidance and topographic mapping in the mammalian visual system. Neuron 20:235-243.

Fujisawa H (1981) Retinotopic analysis of fiber pathways in the regenerating retinotectal system of the adult newt Cynops pyrrhogaster. Brain Res 206:27-37.

Fujisawa H (1987) Mode of growth of retinal axons within the tectum of Xenopus tadpoles, and implications in the ordered neuronal connection between the retina and the tectum. J Comp Neurol 260:127-139.

Gierer A (1987) Directional cues for growing axons forming the retinotectal projection. Development 101:479-489.

Halfter W, Newgreen DF, Sauter J, Schwarz U (1983) Oriented axon outgrowth from avian embryonic retinae in culture. Dev Biol 95:56-64.

Herman J-P, Victor JC, Sanes JR (1993) Developmentally regulated and spatially restricted antigens of radial glial cells. Dev Dyn 197:307-318.

Honda H (1998) Topographic mapping in the retinotectal projection by means of complemetary ligand and receptor gradients: a computer simulation study. J Theor Biol, in press.
Johnston AR, Gooday DJ (1991) Xenopus temporal retinal neurites collapse on contact with glial cells from caudal tectum in vitro. Development 113:409-417.

Mark RF, Freeman TCB, Ding Y, Marotte LR (1993) Two stages in the development of a mammalian retinocollicular projection. NeuroReport 5:117-120.

McLoon SC (1991) A monoclonal antibody that distinguishes between temporal and nasal retinal axons. J Neurosci 11:1470-1477.

McLoon SC, Lund RD (1982) Transient retinofugal pathways in the developing chick. Exp Brain Res 45:277-284.

Monschau B, Kremoser C, Ohta K, Tanaka H, Kaneko T, Yamada T, Handwerker C, Hornberger MR, Loeschinger J, Pasquale EB, Siever DA, Verderame MF, Mueller B, Bonhoeffer F, Drescher U (1997) Shared and distinct functions of RAGS and ELF-1 in guiding retinal axons. EMBO J 16:1258-1267.

Nakamoto M, Cheng H-J, Friedman GC, McLaughlin T, Hansen MJ, Yoon CH, O'Leary DDM, Flanagan JG (1996) Topographically specific effects of ELF-1 on retinal axon guidance in vitro and retinal axon mapping in vivo. Cell 86:755-766.

Nakamura H, O'Leary DDM (1989) Inaccuracies in initial growth and arborization of chick retinotectal axons followed by course corrections and axon remodeling to develop topographic order. J Neurosci 9:3776-3795.

O'Leary DDM, Fawcett JW, Cowan WM (1986) Topographic targeting errors in the retinocollicular projection and their elimination by selective ganglion cell death. J Neurosci 6:3692-3705.

Rabacchi SA, Neve RL, Draeger UC (1990) A positional marker for the dorsal embryonic retina is homologous to the high-affinity laminin receptor. Development 109:521-531.

Rager G, Morino P, Schnitzer J, Sonderegger P (1996) Expression of the axonal cell adhesion molecules axonin-1 and Ng-CAM during the development of the chick retinotectal system. J Comp Neurol 365:594-609.

Roskies AL, O’Leary DDM (1994) Control of topographic retinal axon branching by inhibitory membrane-bound molecules. Science 265:799-803.

Sariola H, Ekblom P, Henke-Fahle S (1989) Embryonic neurons as in vitro inducers of differentiation of nephrogenic mesenchyme. Dev Biol 132:271-281.

Savitt JM, Trisler D, Hilt DC (1995) Molecular cloning of TOP AP: a topographically graded protein in the developing chick visual system. Neuron 14:253-261.

Simon DK, O'Leary DDM (1992) Responses of retinal axons in vivo and in vitro to position encoding molecules in the embryonic superior colliculus. Neuron 9:977-989.

Snow RL, Robson JA (1994) Ganglion cell neurogenesis, migration and early differentiation in the chick retina. Neuroscience 58:399-409.

Sperry RW (1963) Chemoaffinity in the orderly growth of nerve fiber patterns and connections. Proc Natl Acad Sci USA 50:703-710.

Stuermer CA (1988) Retinotopic organization of the developing retinotectal projection in the zebrafish embryo. J Neurosci 8:4513-4530.

Tessier-Lavigne M, Goodman CS (1996) The molecular biology of axon guidance. Science 274:1123-1133.

Vanselow J, Thanos S, Godement P, Henke-Fahle S, Bonhoeffer F (1989) Spatial arrangement of radial glia and ingrowing retinal axons in the chick optic tectum during development. Dev Brain Res 45:15-27.

von Boxberg Y, Deiss S, Schwarz U (1993) Guidance and topographic stabilization of nasal chick retinal axons on target-derived components in vitro. Neuron 10:345-357.

Walter J, Kern-Veits B, Huf J, Stolze B, Bonhoeffer F (1987a) Recognition of position-specific properties of tectal cell membranes by retinal axons in vitro. Development 101:685-696.

Walter J, Henke-Fahle S, Bonhoeffer F (1987b) Avoidance of posterior tectal membranes by temporal retinal axons. Development 101:909-913.

Williams CV, McLoon SC (1991) Elimination of the transient ipsilateral retinotectal projection is not solely achieved by cell death in the developing chick. J Neurosci 11:445-453.

Yamagata M, Herman J-P, Sanes JR (1995) Lamina-specific expression of adhesion molecules in developing chick optic tectum. J Neurosci $15: 4556-4571$. 